The BDJ News section accepts items that include general news, latest research and diary events that interest our readers. Press releases or articles may be edited, and should include a colour photograph if possible. Please direct your correspondence to the News Editor, Arveen Bajaj at the BDJ, 64 Wimpole Street WIG 8YS or by email to bdj@bda.org

\section{Bringing dentistry to Tanzania}

A new programme designed to help bring oral education, rural dentistry and community screening to people in Tanzania has been launched by charities Dentaid and Bridge2Aid.

Dental professionals will be able to volunteer to go to the region of Mwanza on the shores of Lake Victoria for a two-week period organised by Dentaid, where they will work for the ongoing dental programme in the area.

Bridge2Aid led by Dr Ian Wilson has been operating in the Mwanza region of Tanzania since August 2002 delivering primary dental care to all sectors of the community.

As well as operating a clinic in the city, the charity has also developed a programme of screening, oral health education and regular rural 'tooth camps' which take the dental services to the remote areas where $80 \%$ of the region's population live.

Dentaid will pilot a ten-day clinical programme this October and following a full evaluation of the programme, the charities hope to operate quarterly trips from mid 2005 and other countries from 2006.

Professor Raman Bedi, CDO for England and one of the supporters of the project, said that it would help to broaden the vision in the oral health needs of those in developing countries.

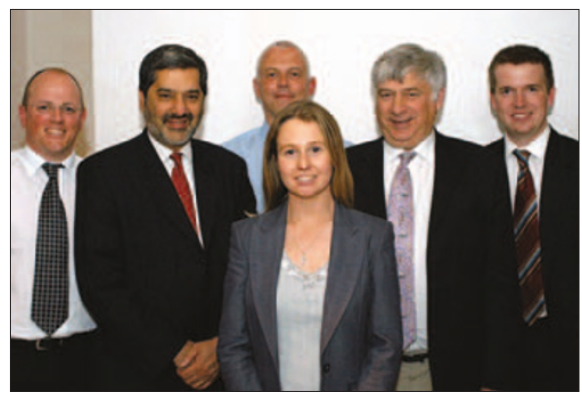

Pictured at the launch dinner (left to right): Mark Topley, Dentaid Head of Communications,

Professor Raman Bedi, CDO England, Dr lan Wilson Director, Bridge2Aid, Dr Jenny Wordley, Dentaid Dental Executive, Brian Mouatt CBE, and Luke Wordley, Dentaid Chief Executive.

\title{
Supporting victims of crime
}

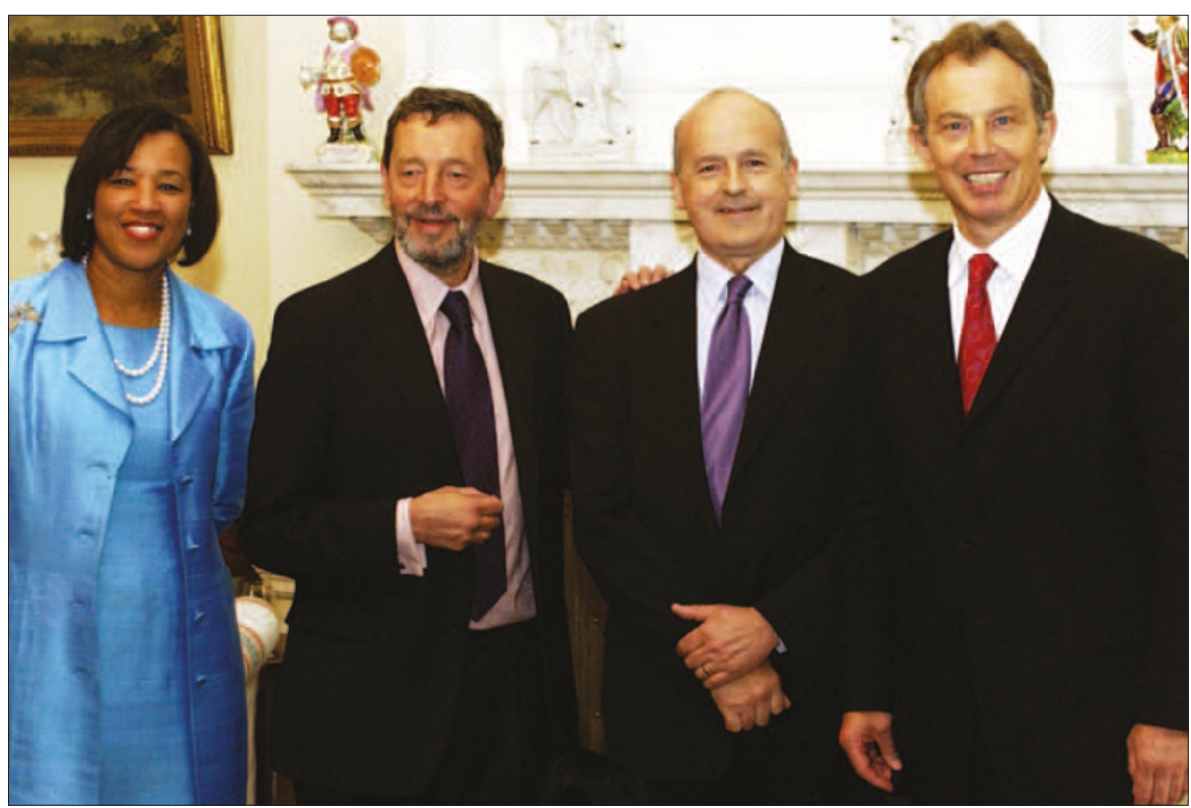

Consultant Surgeon specialising in face and jaw injuries Professor Jonathan Shepherd was a guest at Downing Street recently at an event held to celebrate the work of those involved in supporting victims of crime. Professor Shepherd is a founder Trustee of the national charity Victim Support and founded the prototype Crime Reduction Partnership in Cardiff in 1996. Above left to right: Baroness Scotland of Asthal QC, Minister of State, Home Office, David Blunkett, Jonathan Shepherd and Prime Minister Tony Blair.

\section{Dentists unhappy with Government plans}

Nearly 60 per cent of high street dentists will either reduce their NHS commitment or quit the NHS altogether, according to new research from the British Dental Association (BDA).

The figures form part of a major consultation exercise by the Association, and show dentists' attitudes to the Government's plans for NHS dentistry in England and Wales in April 2005.

The consultation also found that only one in five dentists thought the Government had listened to their concerns.

Only two per cent of high street dentists said that they would increase their NHS work on the back of the Government's proposals and 16 per cent said that they would stop providing NHS dentistry altogether.
The BDA's research also revealed that dentists were frustrated by the lack of information coming from the Government about the changes, which are less than a year away.

John Renshaw, chair of the BDA Executive Board described the NHS dental service as being at breaking point.

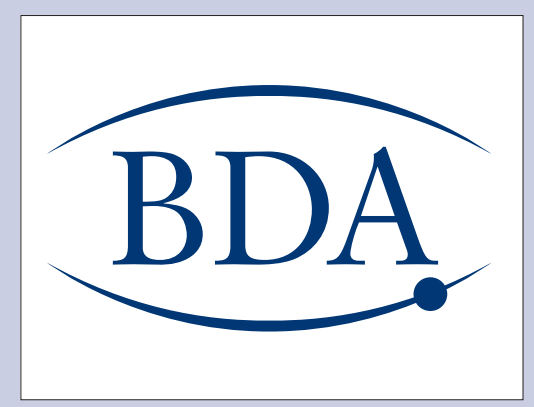




\section{DIARY \\ Winners all round}

June 2004

One in a million: The facts about water

fluoridation

Date: 28.06 .04

Venue: Royal College of Physicians

Contact: Sheila Jones

Tel: +44 (0)1612205223

Email: bfs@bfsweb.org

BDA/BDJ Clinical Seminar: Periodontology

Date: 18.06.04

Venue: Holiday Inn, Oxford

Contact: Kath Blacker, Events Office

Tel: +44 (0) 2075634590

Email: events@bda.org

\section{August 2004}

8th Congress of International Congress of Oral Implantologist/Asia Pacific Section \&t 20th International Symposium of the Asian Oral Implant Academy

Date: 27-29.08.04

Venue: The New Otani, Singapore

Contact: The ICO/AP-AOIA Meeting

Secretariat

Tel: 67343162

Email: singdent@singnet.com.sg http://web.singnet.com.sg/ qualiser/me eting.html

\section{September 2004}

92nd FDI World Dental Congress

Date: 10-13.09.04

Venue: Delhi, India

Tel: +91 1123315834

Email:shastri@tci.co.in

www.tciconferences.com

A student from Glasgow Dental School and a dentist from Bristol were both recent winners of healthcare awards.

Tariq Bashir, aged 21, won the Wrigley Oral Healthcare in Action Dental Student Award 2004 held at the recent BDA Conference and Exhibition. The fourth year dental student won the prize for his information leaflet aimed at educating Asian patients about oral health.

The winning leaflet is illustrated with cartoon images of Jo Hartop, Manager of Wrigley Oral Healthcare in Action people from a range of Asian

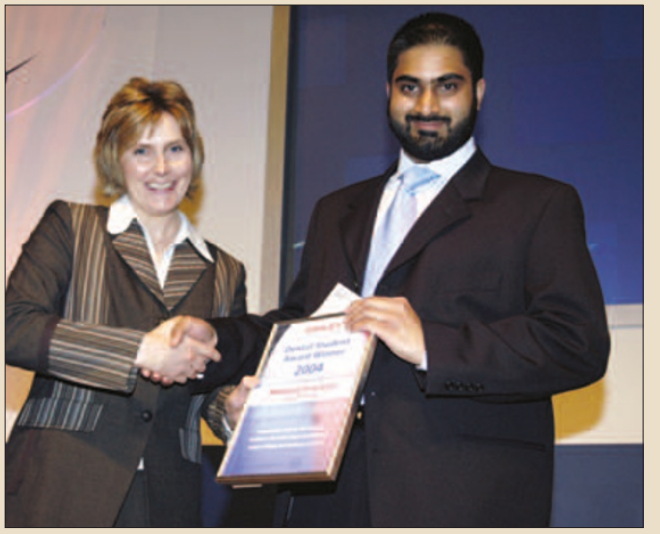
presenting Tariq Bashir with his prize.

backgrounds, and gives simple, easy-to-follow guidance on dental hygiene and diet, as well as advice on smoking cessation and visiting the dentist. He won $£ 1000$ to be split between himself and Glasgow Dental School. The award is offered annually to dental students, student hygienists and student therapists in the UK and Republic of Ireland. Wrigley OHA now plans to produce a patient leaflet communicating the key oral health messages in the four main Asian languages: Gujarati, Hindi, Urdu and Bengali, based on Tariq's design.

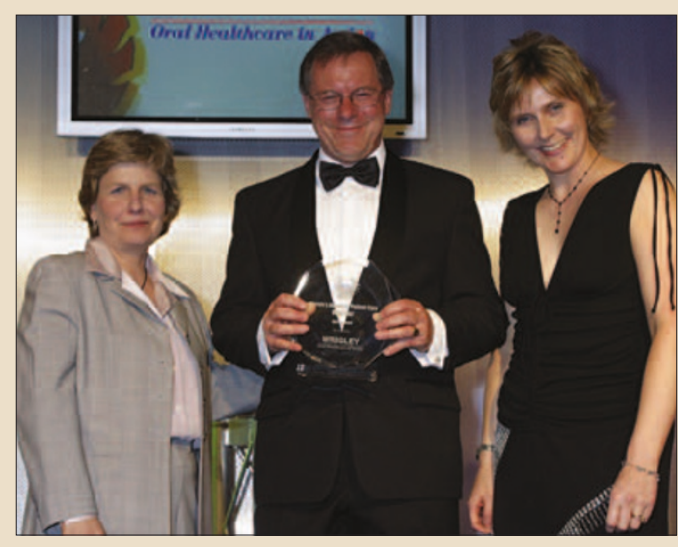

Dr Adrian Reed (centre) with broadcaster Sandi Toksvig (left) and Jo Hartop (right).
Bristol dentist Adrian Reed was the winner of the Wrigley Oral Healthcare in Action People's Award for Patient Care, at the Dental Awards 2004, which recognises dental professionals who show the highest level of care. Dr Reed, of Ashley Down Dental Care in North Bristol, was selected from over 600 nominations for his selflessness in giving up his time over Christmas to help a young boy in pain. The award is unique in that members of the dental profession are nominated by the general public. 


\section{Nottingham practice awarded}

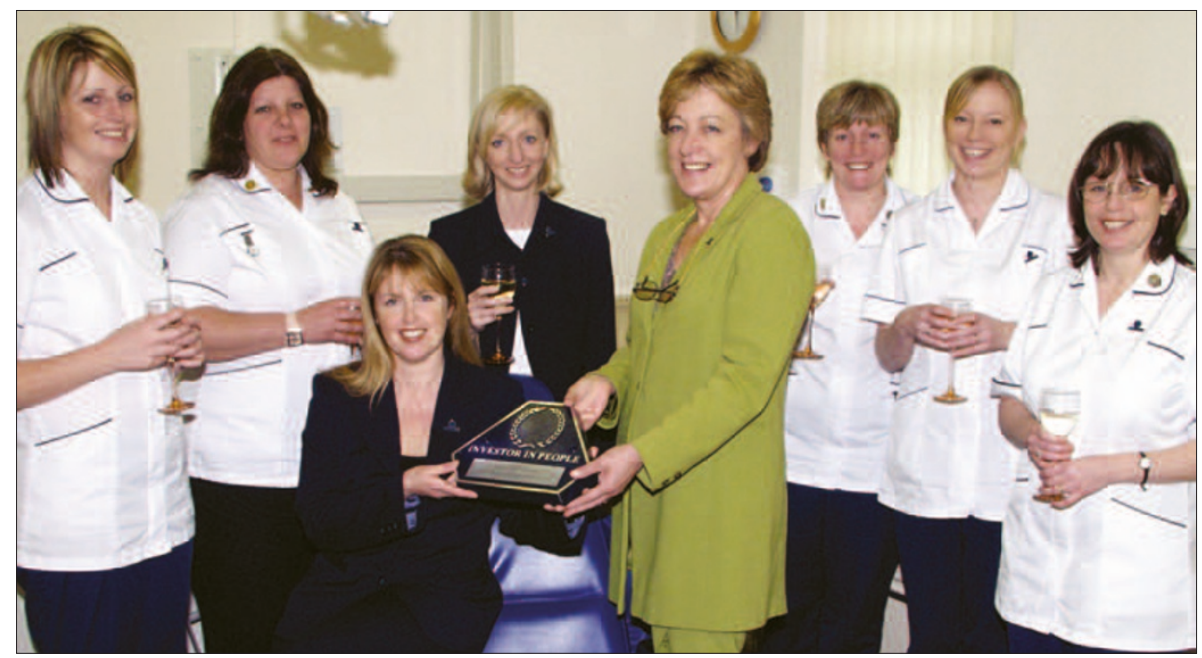

Staff at Cotgrave Dental Care Centre are the latest to become members of the BDA Good Practice Scheme and have been recognised as an Investor in People, all in the same week. The staff were delighted to have received acknowledgement as the practice was amongst the first in Nottingham to achieve recognition. The Good Practice Scheme proves to patients that a practice is committed to working to standards set by their professions' national association. Above: Dentist Jane Loftus (sitting) receives the award from Mary Mitton Workforce Development Advisor for Business Link Nottinghamshire.

\section{Branch President inducted}

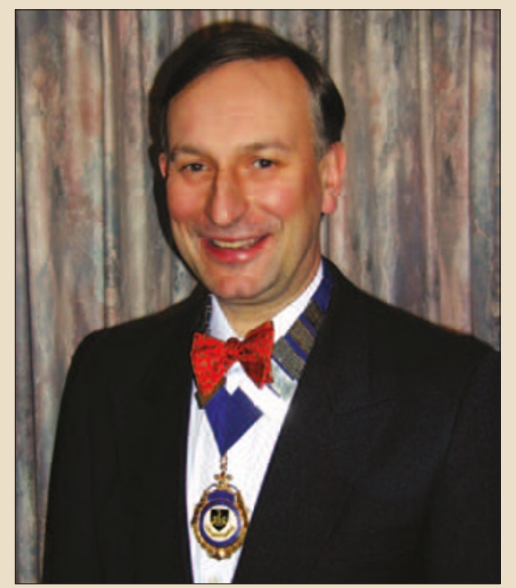

Dr Jerry Asquith was recently inducted as the new President of the Middlesex and Herts branch of the BDA at its annual scientific meeting in Florence. Dr Asquith has been a practising dentist in Ruislip for the past 16 years and is Chairman of Hillingdon Local Dental Committee.

\section{New Chair at CODE announced}

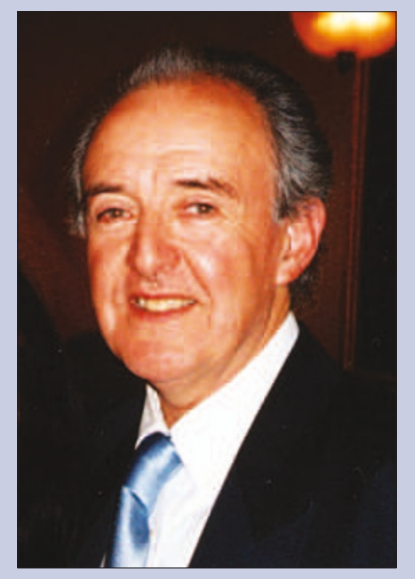

Edwin Bonner has recently become the new Chair of the Confederation of Dental Employers (CODE). A founding member of CODE, he has served on the CODE Council from 1991. A registered specialist prosthodontist as well as an experienced lecturer, he is regularly published in dental journals on practice management issues.

\section{Promoting smoking cessation}

Healthcare professional associations such as the FDI have agreed to promote a new code of conduct to stem trends in tobacco use. Participants, who met at the World Health Organisation (WHO) earlier this year, included professional associations representing pharmacists, dentists, nurses, midwifes, chiropractors and physicians.

During the discussions, professionals vowed to increase and strengthen tobacco surveillance, cessation programmes, ensure access to tobacco-free healthcare facilities and implement education and community advocacy programmes.

Dr Vera Luiza da Costa e Silva, Director of the Tobacco Free Initiative, WHO, said that if, for example, dentists warned all their patients that smoking could cause excess plaque, yellowing teeth and contributed to tooth decay, as well as a fivefold increased risk of oral cancer, the impact on smoking would be dramatic. 